\title{
sciendo
}

\section{RELATIONSHIP BETWEEN THE FINANCIAL INDICATORS AND THE IMPLEMENTATION OF TELEWORK}

\section{Miroslava Vlčková ${ }^{1}$, Zuzana Frantíková $^{2}$, Jaroslav Vrchota $^{3}$}

\begin{abstract}
In most European countries, teleworking or homeworking is used in various forms that differ from one another by its legal regulation. The paper examines the SME's in the Czech Republic from the perspective what makes them to adopt telework using the financial indicators. We hypothesized that employer adoption of telework would depend on some economic factors. The empirical evidence showed that a typical company that uses telework is a company with higher ratio of liabilities and therefore lower ratio of equity, a lower ratio of fixed assets, higher sales, lower inventory, higher labour productivity and higher value added per employee, higher return on equity, higher personnel costs, higher average wages. Within the analysed enterprises, 16 indicators were assessed; the 9 indicators showed the difference between companies that use telework and companies that do not use telework. The research shows a typical company that uses telework.
\end{abstract}

\section{Keywords}

Telework, SME’s, Financial and Economic Indicators, Mann-Whitney $U$ test

\section{Introduction}

Telework as a concept was first introduced as telecommuting by Jack Nilles (Nilles, 1976). He coined it while he was stuck in a traffic jam in Los Angels (Kurland and Bailey, 1999). In the 1980's in the USA, there was a big emphasis on cutting costs from the employer's side and on the ecological problems because California struggled against the air pollution caused by the immense usage of cars (Kurland and Bailey, 1999; Handy and Mokhtarian, 1995; Mannering and Mokhtarian, 1995). The adoption of telework in the USA lead into the reduction of the expense of maintaining office space (Kurland and Bailey, 1999). Later,

\footnotetext{
${ }^{1}$ University of South Bohemia, Studentská 13, České Budějovice, Czech Republic.

E-mail: mvlckova02@ef.jcu.cz.

${ }^{2}$ University of South Bohemia, Studentská 13, České Budějovice, Czech Republic.

E-mail: zfrantikova@ef.jcu.cz.

${ }^{3}$ University of South Bohemia, Studentská 13, České Budějovice, Czech Republic.

E-mail:vrchota@ef.jcu.cz.
} 
the increase of telework in the USA was caused allegedly due to the tragedy occurred on September 11, 2001 and safety measurements implemented in the country (Potter, 2003). Unlike the Industrial Age where big industrial centres were built up telework represents an opposite tendency (Potter, 2003). Among other factors stimulating the growth of telework were the boom of IT technology and the accrual of dual-earner households and due to this fact, the need for work-life balance (Potter, 2003). In the USA articles differ four types of telework: home-based telecommuting, satellite offices, neighbourhood work centre and mobile workers, (Potter, 2003; Kurland and Bailey, 1999). However, the reasons to adopt telework has changed recently. More recently, organizations have begun to view telecommuting as a tool to attract and retain top personnel in fields with short labour supplies. The paper examines the organizational readiness to implement telework (Steil and Barcia, 2001).

Defining the concept of 'telework' is crucial, because its fluidity has been subject to many interpretations (Sullivan, 2003; Garrett and Danziger, 2007). Telework is defined as: 'ANY form of substitution of information technologies (such as telecommunications and computers) for work-related travel; moving the work to the workers instead of moving the workers to work' (Nilles, 1998). Telecommuting is defined as: 'Periodic work out of the principal office, one or more days per week either at home, a client's site, or in a telework center' (Nilles, 1998). Hill, Ferris and Märtinson (2003) write that 'to date, most telework research has focused on home-based telecommuters, and these studies have generally had relatively small sample sizes, suffer from selection bias, and rarely use a traditional office comparison group (Dubrin and Barnard, 1993; McCloskey and Igbaria, 1998; Ramsower, 1985)'.

Teleworking first came into usage in its present context to indicate work remote from the office, nevertheless in most cases teleworking is done from home, and thus sometimes titled 'homeworking' (Baruch, 2000). Baruch (2000) introduces studies that claim that teleworking uses electronic media as its main 'tool' while home-working might be the old-fashioned 'sweatshop' manufacturing. There is telecommuting of full and part-time basis. In this paper, we identify telework in terms of a practice of conducting ordinary work at locations other than the regular workplace at least one day a month. According to the approaches mentioned in the literature it is obvious that telework is not suitable for everybody and it has its pros and cons. The focus of the paper is to evaluate based on financial analysis types of companies that are or are not more likely to use telework. These ratio indicators are based mainly on the indicators such as return, productivity, personnel costs or analysis of units of assets. Financial analysis represents basic source of information thanks to it is possible to evaluate the state of financial health of the company and it creates necessary condition for future decisions on financial state of the company. In the Czech Republic, telework is regulated in Section 317 of Act No. 262/2006 Sb., the Labour Code. It is defined as the regime of work of an employee who does not work at the employer's place of work but, under the agreed conditions and who performs a negotiated job during the working hours he/she plans. Sections regarding working hours, overtime, compensation of wages, spare time off in case of overtime and compensation of wages in case of some personal obstacles at the employee's side cannot be applied 
in case of telework. On the other hand, employers should compensate the costs paid by the distant/home employees, however this is regulated implicitly and that's why most employers do not keep the regulation and do not compensate the costs employees pay by doing their work from home. Therefore, the new proposal of the amendment of Labour Code counts with the implementation of new regulation consisting in the specification of the employers' duty to compensate the costs arisen on employee's side.

Unlike the legal regulation in other countries, in the Czech Republic the regulation of telework does not it emphasizes the usage of IT technology and the regularity of using the telework but the freedom regarding the working hours at the employee's side.

In accordance with the European Trade Union Confederation, telework is defined as a form of organizing and/or performing work, using information technology, where work, which could also be performed at the employers' premises, is carried out away from those premises on a regular basis (Implementation, 2006).

Teleworking statistics can be used for a range of analyses, both macroeconomic, if we see work as one of the factors of production, as well as for analysis of productivity, or competitiveness in the labour market. Analyses can also be carried out from the point of view of social aspects related to diverse ways of employing workers. The productivity is also one of the sets of human capital performance indicators (Krstić and Bonić, 2016).

\section{Literature review}

It is true that the concepts 'telecommuting' or 'teleworking' do not have a stable definition and may be the reason why the results of surveys may differ a lot. They are usually defined as work performed using information technology (not always, e. g. (Muhammad, Ottens, Ettema and de Jong, 2007), carried out away from employers' premises (Eurofound and the International Labour Office, 2017) Some time, the concepts are specified only on work performed from home, some time there is a condition of the percentage of time they have to work from home (Caulfield, 2015).

Comparing European countries there is a noticeable significant difference between the North and Eastern Europe (except Germany), more than one third of the population uses the possibility of a minimally part time job from home a Southern and Eastern Europe where this trend is significantly lower (Eurofound and the International Labour Office, 2017).

From other countries for example in the USA in $201028 \%$ working population used telework (Baltina and Vitola, 2014), in 2012 minimally once a week 20\% worked from home. From Indian population outside the agriculture in 2015 19\% of workers worked from home (Eurofound and the International Labour Office, 2017).

Comparing the possibility of telework in different culture areas, we can see that telework is more accessible for managerial positions in Anglo-Saxon countries in countries of Eastern Asia or Latin America (Aline et al., 2012). From the perspective of the employee' interest to have the possibility of telework, it is clear that e.g. Germany does not use its potential to adopt telework - two thirds of the employees on work position enabling telework, do not use telework even though they would like to, but they have not been given the chance (Brenke, 2016). In Egypt 50\% of people working in accounting, IT or academic sphere 
does support telework. The implementation of teleworking also depends on the level of education. A higher level of education increases the chances of getting a better job, and later of obtaining a higher level of support (Birčiaková, Stávková and Antošová, 2015).

Figure 1: Percentage of employees doing T/ICTM in the EU 28, by category and country

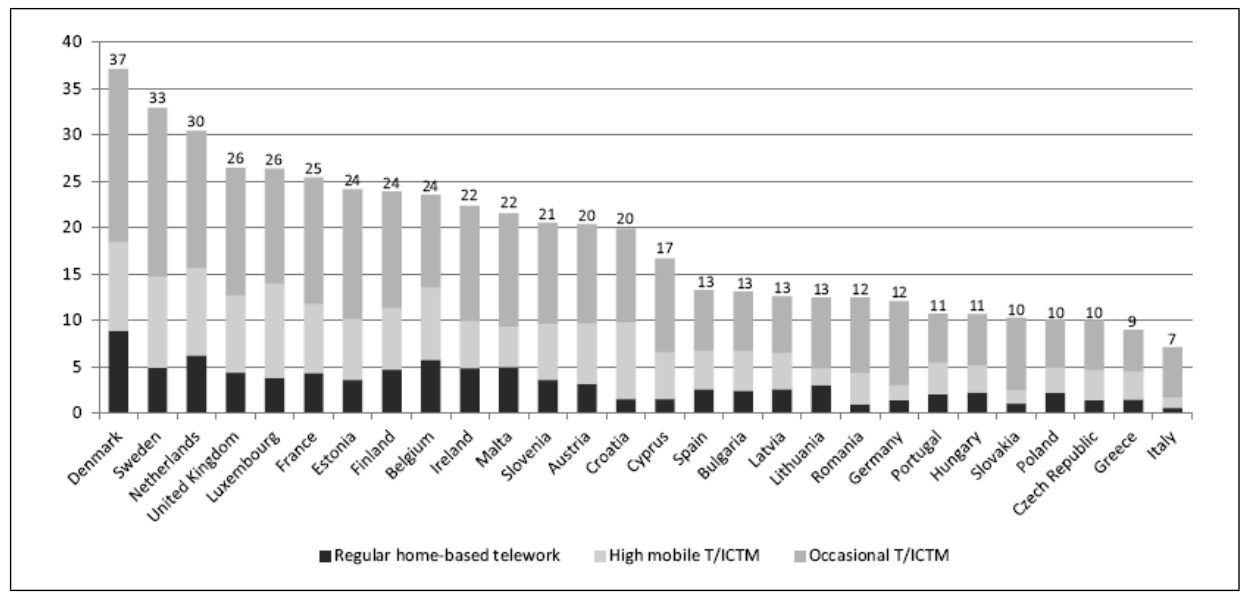

Source: EWCS (2015)

Although telework can be defined in many ways, we are interested in all situations where an employee works from home at least one day a month. However, these estimates are typically based on cases where employees regularly or always use telework and could exclude cases where employees telework on an occasional or irregular basis. For employers, implementing telework potentially generates cost savings by adapting available labour levels to fluctuations in demand for their services, and by reducing or restraining the need for real estate, office space, supplies (Peters et al., 2010; Verbeke et al., 2008) and other overheads (Morgan, 2004).

Several researchers have found a small but robust empirical relationship between the use of specific work practices and firm level outcomes such as profitability and productivity (e.g. Delery and Doty, 1996; Gerhart et al., 2000; Huselid, 1995; Jiang et al., 2012; Wright and McMahan, 1992). One reason why strategically chosen organizational practices can lead to improved firm performance is that the human capital of a workforce can be unleashed and fully utilized (see Wright and McMahan, 2011).

Many papers focus on the influence of telework on the effectivity, productivity, satisfaction, stress and leisure time of the employee or on similar areas. The biggest advantage of the model of work is the elimination of time dedicated to telecommuting (e.g. Abdel-Wahab, 2007; Haddad, Lyons and Chatterjee, 2009). The higher satisfaction with work and the sensation of autonomy are ones of typical features of teleworking (Aline D. et al., 2012; Baltina and Vitola, 2014; Brenke, 2016; Redman, Snape and Ashurst, 2009). The European survey has showed that telework boosts productivity and the possibility to relax during the working hours, but it brings longer working hours, higher need to work overtime and higher level of stress (Eurofound and the International Labour Office, 2017; Martin and 
MacDonnell, 2012). On the other hand, other surveys show that the level of stress is decreased by the telework (Ravi and David, 2007; Redman et al., 2009). However there are opinions that the deletion of differences between work time and leisure time may lead to serious health problems (Peters and van der Lippe, 2007).

One of the most interesting problematic in this area is the relation between work from home and the distance home to work. The studies in the countries do not bring a clear answer if the primary hypothesis that telework relates to the equal area distribution of population is confirmed. The research performed in Ireland, South Corea, Netherlands, Canada or Finland outline that it could be like this (Caulfield, 2015; Helminen and Ristimäki, 2007; Muhammad, Ottens and Jong, 2008; Muhammad et al., 2007; Kim, 2016; Tayyaran and Khan, 2007). On the other hand in Greece, Lithuania or in other Dutch research these tendencies do not show confirm that, rather the contrary (Polydoropoulou and Tsirimpa, 2012; Armitage, 2000; de Graaff and Rietveld, 2007; Vilhelmson and Thulin, 2016).

Most of these work, however, only explored the advantages and disadvantages of remote work without accepting a wider perspective of research to examine deeper issues and the roles of different interest groups. There was also a significant increase in the number of teleworks in different sectors during this period. The aim of this article is to fill a certain gap in this area and look at telework from other aspects in terms of cost and in terms of selected indicators of financial analysis.

Telework is associated with several costs and benefits, including a reduction in overhead costs for the company, the need for office and parking space, energy consumption in the office, increased productivity, reduced absenteeism, maintenance of specialized staff, reduced fuel consumption and air pollution, and many others (Kitou and Horvath, 2008). Financial analysis is a basic source of information to assess the state of the company's financial health and to create a prerequisite for future financial decision-making (Brigham, 2005). The results of the financial analysis provide information not only to the company for its management but also to third parties such as investors, creditors, state bodies and others (Synek, 2011). The indicators of financial analysis are the basis for the company evaluation.

The financial analysis consists of steps that are interlinked. First it is necessary to choose appropriate indicators and the manner of its calculation. The next step is represented by the comparison of the selected data with the competition in the selected industry field (it means if the company is under average, average, or over average), and by the comparison of the data with the historical results of the company, the comparison with the plan and the comparison with the departments of the company. In addition, the interrelationship between the individual financial performance indicators of the company should be established and completed by the evaluation of the results. 


\section{Methodology}

Due to data distribution and availability of statistical programs, it was chosen for hypothesis testing Mann-Whitney $U$ test. The Mann-Whitney $U$ test was preferred to the $t$-test because it is more widely used than the $t$-test and for large samples from the normal distribution, the loss of efficacy compared to the $t$-test is only $5 \%$. The test involves the calculation of a statistic, usually called $U$, whose distribution under the null hypothesis is known. $U$ is then given by:

$$
U_{1}=R_{1}-\frac{n_{1}\left(n_{1}+1\right)}{2}
$$

where $n_{1}$ is the sample size for sample 1 , and $R_{1}$ is the sum of the ranks in sample 1 . An equally valid formula for $U$ is:

$$
U_{2}=R_{2}-\frac{n_{2}\left(n_{2}+1\right)}{2}
$$

The smaller value of $U_{1}$ and $U_{2}$ is the one used when consulting significance tables. The sum of the two values is given by:

$$
U_{1}+U_{2}=R_{1}-\frac{n_{1}\left(n_{1}+1\right)}{2}+R_{2}-\frac{n_{2}\left(n_{2}+1\right)}{2}
$$

Knowing that $R_{1}+R_{2}=\frac{N(N+1)}{2}$ and $N=n_{1}+n_{2}$, and doing some algebra, we find that the sum is $U_{1}+U_{2}=n_{1} n_{2}$.

Financial indicators:

$$
\text { Debt ratio }=\frac{\text { Liabilities }}{\text { Total assets }} \times 100
$$

The debt ration indicator determines that the greater equity ratio is, the greater the security pillow against the losses of creditors in the event of liquidation is, too. It shows how much of liabilities falls on CZK 1 of total assets (Helfert, 2001). Liabilities in this indicator include both short-term and long-term liabilities, including bank loans, which are dealt separately from other liabilities in the balance sheet. If the indicator is higher than the industry average, the company will have difficulty raising additional resources without first increasing equity (Synek, 2011). The low value of this indicator is preferred by creditors. On the other hand, owners are looking for a higher operating leverage to multiply their revenue (Brigham, 2005). The recommended value varies by business size and business type. In general, it is recommended that the value is less than 50\%, however higher values do not necessarily mean a problem; it is the comparison with past periods which is important (Kislingerová, 2010).

$$
\text { Return on equity }(R O E)=\frac{E B I T}{\text { owner's equity }} \times 100
$$


If a company is funded only by owner's equity, the ROE may be the same as the return on employed capital (ROCE). The comparison with other companies makes sense only in the same field of industry (Holečková, 2008). For ROE, it is advisable to look at the development trend over a longer period.

$$
\text { Labour productivity per month }=\frac{\frac{\text { Sales }}{\text { Average number of employees }}}{12}
$$

Productivity is an economic indicator, whose substance is the measurement of the performance of one of the production factors (Helfert, 2001). The formula has the disadvantage that it may be difficult to find objective and correct data that are appropriate for all job positions (Brigham, 2004). Changes in labour productivity is also one of the six factors that affect the overall change in employment (Hudcovský et al., 2017).

$$
\text { Value added per employee }=\frac{\frac{[\text { incomes }-(\text { operation costs }- \text { personnel costs })]}{\text { Average number of employees }}}{12}
$$

$$
\text { Personnel costs per employee }=\frac{\text { Total personnel costs }}{\text { Average number of employees }}
$$

Personnel costs include aggregate wage costs plus additional costs that the employer pays for employees, i.e. compulsory social insurance and public health insurance. These are costs related, for example, to remuneration based on employment relationships, social security and health insurance contributions, etc.

$$
\text { Capital ratio of total assests }(v \%)=\frac{\text { Fixed assets }}{\text { Total assets }} \times 100
$$

Assets as one of the key elements of the balance sheet represent the result of past events and are expected to bring the company future economic benefits (Kislingerová, 2010). Fixed assets are long-term, fixed and non-current. They include asset components that serve the business activity for a long time, meaning more than 1 year and are consumed over time. The indicator says how many percent of total assets are fixed assets (Scholleová, 2008).

$$
\text { Capital ratio of sales }(\%)=\frac{\text { Fixed assets }}{\text { Total sales }} \times 100
$$

Revenue or operating income is the amount of money the company has received from all its activities for a certain period, regardless of whether it has been settled during that period (Brigham, 2004).

$$
\text { Equity Ratio in } \%=\frac{\text { Own equity }}{\text { Total debts }} \times 100
$$


Equity ratio indicates what part of the company's assets is funded by shareholders' equity (Wild, 2010). It is a complementary indicator to the creditor risk indicator and their total should be approximately 1 . This indicator is among the debt ratios (long-term financial stability) and it reaches values from the interval $\langle 0 ; 1\rangle$. This indicator is one of the most important indicators of debt ratio for assessing the financial situation of a company, it is particularly important for creditors (Scholleová, 2008).

$$
\text { Inventory indicator on total assests }(v \%)=\frac{\text { Inventories }}{\text { Total assets }} \times 100
$$

This indicator tells how many percent of enterprise's total assets have inventories. The value of this indicator is higher for business and manufacturing companies, lower value have service providers.

\section{Empirical data, analysis and results}

In the analysis, a zero hypothesis was always stated that the financial indicators (Debt Ratio in \%, Return on equity of EBIT in \%, Labour productivity in CZK thousand per month, Value added per employee in CZK thousand per month, Personnel costs per employee in CZK thousand per month, Capital ratio of total assets in \%, Capital ratio of sales in \%, Equity ratio in \%, Inventory Indicator on Total Assets in \%) in case of companies that use telework (telework companies) and companies that do not use telework (non-telework companies) coincide on the basis of analysed data and an alternative hypothesis that telework companies achieve better results in the chosen indicators. A total of 16 indicators were analyzed within the surveyed enterprises.

The data used for the analysis was gained from two sources. The first source is the databases Albertina Gold Edition, whereof the data for the calculation of the financial indicators from the balance sheet) and from the profit and loss statement. Another source was a survey of telework where, based on a questionnaire survey, almost 53,365 businesses were approached. Return rate was 1076 businesses, however usable results were achieved only at 1018 businesses.

Using a two-volume Wilcoxon test (Mann-Whitney $U$ test) at the selected significance level $\alpha=0.05$, hypotheses $\mathrm{H} 0=x 0.50-y 0.50=0$, where it is assumed that the value of the financial indicator for telework companies and non-telework companies is at the same level and the hypothesis $\mathrm{HA}=x 0,50>y 0,50$, which presumes that telework companies achieve better results. In both hypotheses, $X=$ telework companies and $Y=$ non-telework companies.

The table below lists the results of each hypothesis, based on a $p$-value that is greater than or less than the $\alpha$, we reject, or confirm the zero hypothesis. Later, we incline, according to the value of $Z$, to the right-hand or left-handed variant. 
Table 1: Indicators demonstrating differences between telework companies and non-telework companies

\begin{tabular}{|l|c|c|c|c|c|c|c|}
\hline Variable & YES & NO & U & Z & p-value & Z edited & $\begin{array}{c}\text { p-value } \\
\text { edited }\end{array}$ \\
\hline Debt Ratio in \% & 234530 & 52372 & 40744 & 2,172 & 0,0299 & 2,1721 & 0,02985 \\
\hline $\begin{array}{l}\text { Return on Equity (ROE) } \\
\text { in \% }\end{array}$ & 235585 & 51317 & 39689 & 2,609 & 0,0091 & 2,60981 & 0,00906 \\
\hline $\begin{array}{l}\text { Labour Productivity in } \\
\text { CZK thousands/month }\end{array}$ & 230000 & 48631 & 37155 & 3,284 & 0,0010 & 3,2843 & 0,00102 \\
\hline $\begin{array}{l}\text { Value Added per } \\
\text { Employee in CZK } \\
\text { thousands/month }\end{array}$ & 228907 & 48977 & 37501 & 3,110 & 0,0019 & 3,1107 & 0,00187 \\
\hline $\begin{array}{l}\text { Personnel Costs per } \\
\text { Employee in CZK } \\
\text { thousands/month }\end{array}$ & 230253 & 48378 & 36902 & 3,391 & 0,0007 & 3,3921 & 0,00069 \\
\hline $\begin{array}{l}\text { Capital ratio of total } \\
\text { assets in \% }\end{array}$ & 220876 & 66027 & 37561 & $-3,492$ & 0,0005 & $-3,4930$ & 0,00048 \\
\hline Capital ratio of sales in \% & 219777 & 67125 & 36462 & $-3,948$ & 0,00008 & $-3,9487$ & 0,00008 \\
\hline Equity Ratio in \% & 223910 & 62235 & 40595 & $-2,116$ & 0,0342 & $-2,1167$ & 0,03428 \\
\hline $\begin{array}{l}\text { Inventory Indicator on } \\
\text { Total Assets in \% }\end{array}$ & 223025 & 63120 & 40315 & $-2,321$ & 0,0202 & $-2,3259$ & 0,02003 \\
\hline
\end{tabular}

Source: Database Albertina Gold Edition, own research, authors' processing

During the analysis, 16 indicators were analyzed in total within the surveyed enterprises, 9 indicators show the difference between telework companies and non-telework companies (see table 1) and 7 indicators did not show any differences.

Debt ratio is one of the indicators of indebtedness. These indicators show the relationship between equities and liabilities of financing of a company and measure the extent to which the company uses its finance to settle debts (Synek, 2011). However, debt ratio is not only a negative indicator. Its growth can contribute to the return on assets and hence the higher market value of the business. On the other hand, it increases the risk of financial instability (Kislingerová, 2010). According to the company's primary goal of maximizing profits, it is necessary to examine whether a company is indebted, over-accredited, or whether the capital resources are appropriately utilized and that the company is not over-capitalised. The long-term financial stability of the company is conditioned by the proper structure of resources (optimal ratio between equities and liabilities) and by selecting the most suitable liabilities. 
Boxplot 1: Indicators of debt ratio and ROE in comparison with the entity with or without telework

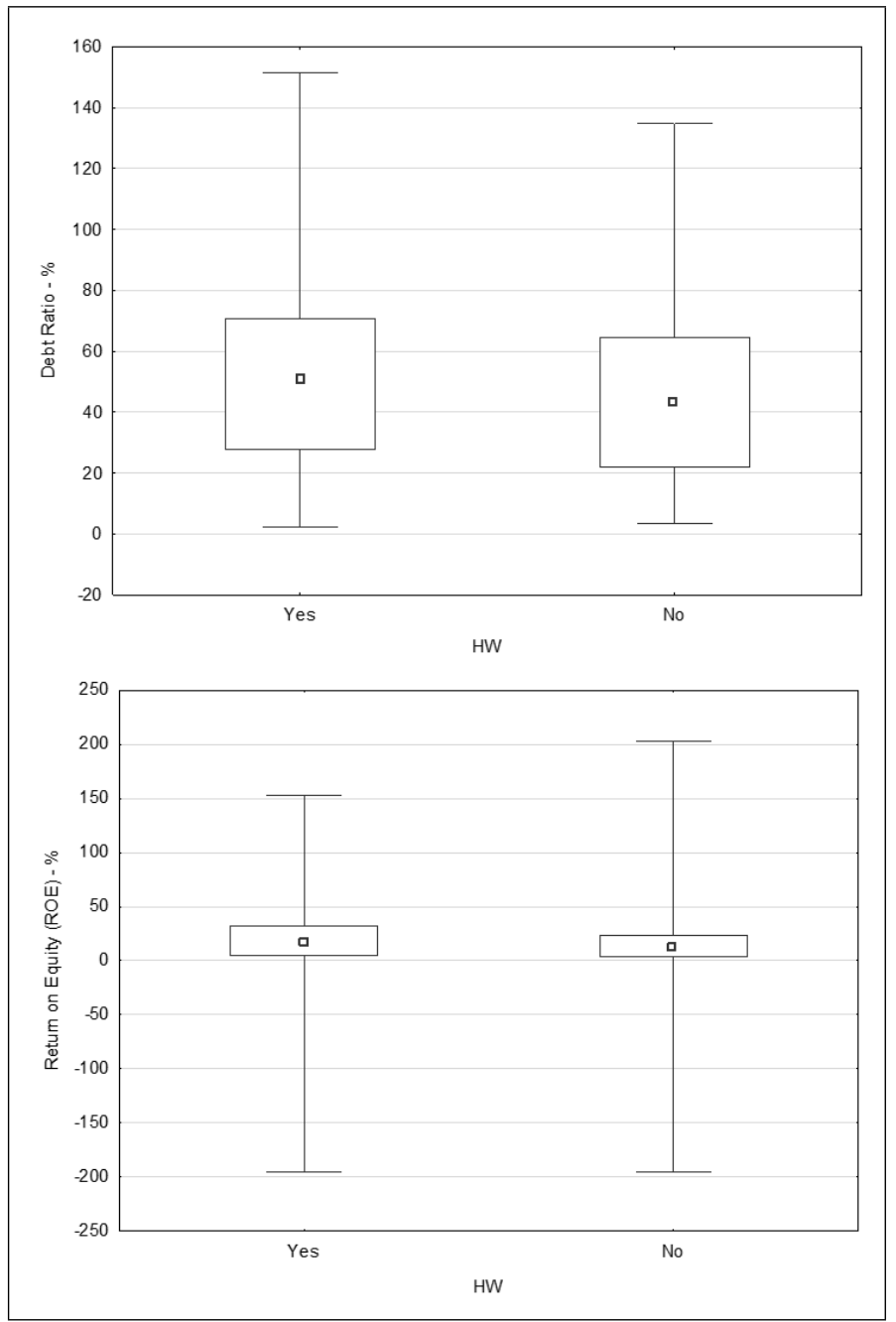

Source: Database Albertina Gold Edition, own research, authors' processing

Based on our research, it is evident from boxplot 1 that the debt ratio of telework companies is higher than of non-telework companies. This can be caused mainly due to the field of industry, as telework companies are generally trading companies with a higher share of liabilities, while non-telework companies are primarily manufacturing companies. Their mean value is over $50 \%$, whereas the mean value of the indicator for non-telework companies is over $40 \%$. A further research showed that the highest debt ratio was in the wholesale, retail and services sectors ( $63.8 \%$ on average), as well as in the administrative 
activities (58.3\% on average). On the contrary, the lowest debt ratio is found in farms (48\% on average), construction enterprises (51.7\% on average) and manufacturing enterprises (54.1\% on average). These values confirm not only the hypothesis that telework companies have higher debt ratio, respectively they use more liabilities but also that non-telework companies are mainly manufacturing companies, construction companies and agricultural enterprises.

Return indicators bring business efficiency information and evaluate the profitability of the business. The higher the values are, the better. It can also be asked whether it is more efficient to work with equities or with liabilities. Return on equity (ROE) is one of the indicators of profitability and expresses how effectively an organization manages funds injected by shareholders or associates. The Return on equity indicator does not include information on dangers of return on equity (Holečková, 2008). According to our research - see boxplot 1 , it is evident that the return on equity for telework companies is higher than for non-telework companies. This may be since these companies achieve better results or have lower equity. In connection with the analysis of the previous indicator, it is obvious that this is due to lower equity or a combination of a higher economic result and lower equity. Their mean value is around $15 \%$, while mean value of the indicator for non-telework companies is around $10 \%$. The recommended value depends on many factors (e.g. industry or macroeconomic developments), but in stable economic systems it should be over $12 \%$. Paradoxically, high debt ratio (low equity ratio) leads to a better value of the indicator. ROE is mainly used by shareholders and when analysing it, it is necessary to look at the debt ratio, too. To examine this hypothesis, an analysis of the profit or loss, resp. EBIT was made. The average EBIT for all industries was 9,015,000.00 CZK. The highest values were achieved by IT companies (average EBIT is CZK 16,863 thousand), where it is obvious that there is a large adoption of telework. On the other hand, EBIT was below the average in case of transport companies or in the construction sector (again, the hypothesis that telework is rare here, was confirmed). Similarly, the above-mentioned hypothesis was confirmed in case of the equity indicator. The mean value of equity for all sectors was CZK 110,637 thousand. The lowest values (and hence the probability that these enterprises have adopted telework) were achieved by companies operating in administration (the average value of equity is CZK 23,471) in the field of professional, scientific and technical activities (average value of equity is CZK 31,026) and wholesale, retail and services (average value of equity is CZK 39,667). On the contrary, values over the average value of equity for all sectors were achieved in the transport sector (average value of equity is CZK 1,075,758) and services (average value of equity is CZK 131,193.00). The indicator of labour productivity in thousands per month indicates how high the sales (in thousands CZK) per employee for the selected time interval (i.e. 12 months) are. We have found that labour productivity in telework companies is higher than in non-telework companies - see boxplot 2. In other words, these companies achieve higher sales per employee. This may be due to the following factors that affect labour: 
* type of management,

* motivation of employees,

* qualification of employees,

* natural and climate conditions,

* technology.

Boxplot 2: Indicators of labour productivity and value added per employee in comparison with telework companies and non-telework companies

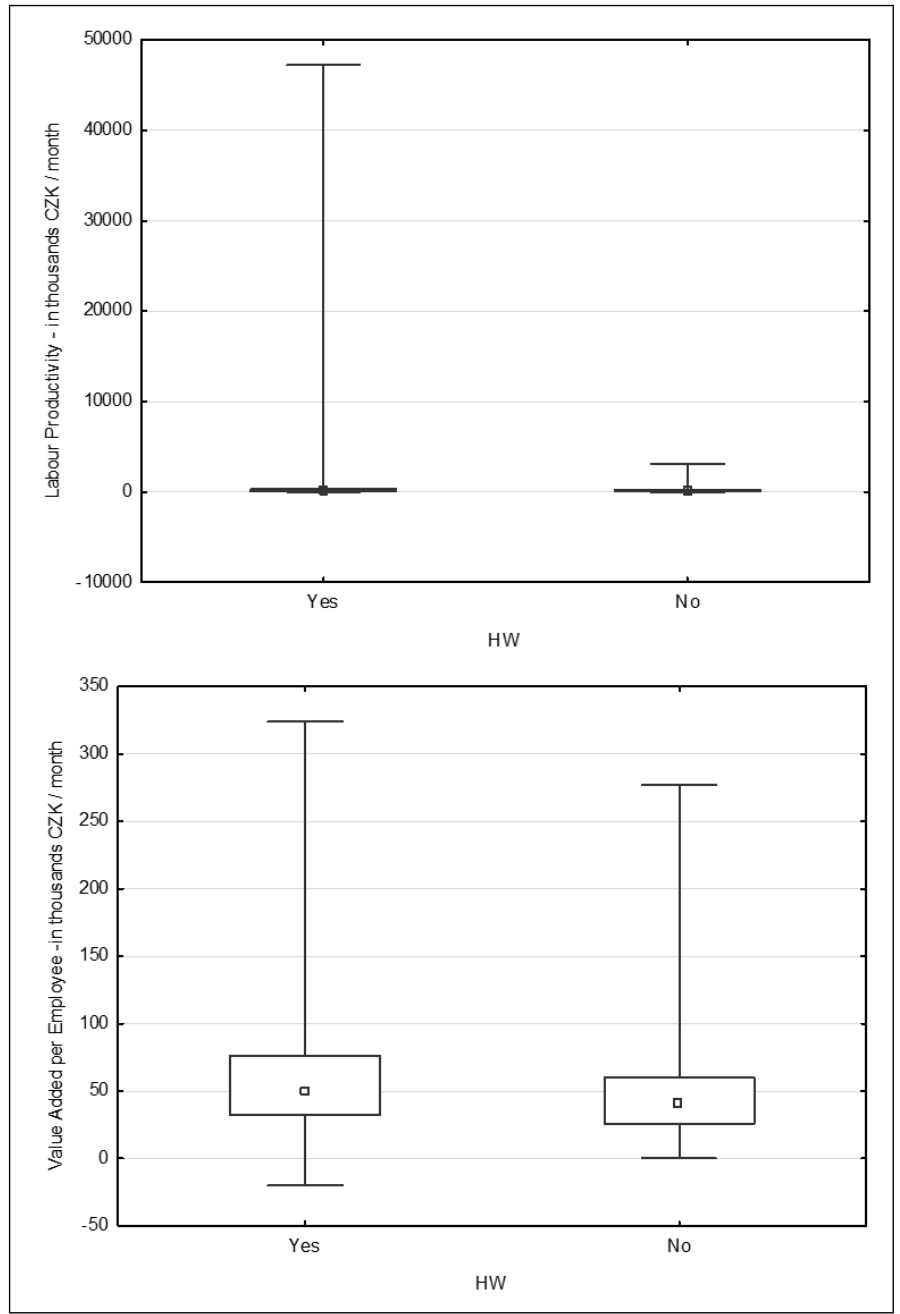

Source: Database Albertina Gold Edition, own research, authors' processing 
The growth of the indicator in the temporal arrangement is positive. The value of the indicator can be got by comparing it with another company from the same or a similar field. Currently, it ranges from CZK 360 to 840 thousand, but top companies achieve many better results.

Added value is an economic indicator measuring the company's financial performance. Simply said, this is the difference between the net operating profit achieved and the total cost of capital (Helfert, 2001). If we relate this figure to the number of employees, we will get the added value of human capital (Kislingerová, 2010). According to the research, the value added per employee for telework companies is higher than for non-telework companies - see boxplot 2. This may be since these companies achieve higher incomes (the analysis of this indicator is confirmed by the validity of the previous productivity indicator, where telework companies achieve higher sales and hence higher incomes). Their mean value is more than CZK 50,000.00 per month, while the mean value of the indicator for telework companies is around 40,000.00 CZK per month. In this way, it is certainly not possible to monitor the added value of each individual employee, but the figure of the mean value added of human capital is a very important benchmark of an enterprise with its competitors.

The personnel costs per employee indicator in thousands per month is calculated by dividing the total personnel costs by the number of employees and by 12 months. Based on the research, it is evident that the personnel costs of per employee in telework companies are higher than in non-telework companies (see boxplot 3). This may be due to higher wages for employees in telework companies, as these employees usually work at higher hierarchical levels within the organizational structure of an enterprise. Their mean value is more than CZK 35,000.00 per employee per month, while the mean value of the indicator for non-telework companies is around CZK 30,000.00 per employee per month.

In the same trend, the average monthly wage in thousands per month. The average monthly wage represents the share of wages without other personnel costs per employee of the registered number per month. These are gross wages, i.e. before the reduction in premiums for public health insurance and social security, advance payments of income tax and other statutory or employee-agreed deductions.

The indicator, the capital ratio of total assets in $\%$, is calculated as the ratio of fixed assets/total assets. According to the research, it is evident that the capital ratio of total assets in telework companies is lower than in non-telework companies (see boxplot 3). This is mainly since telework companies typically operate in trade and services, while nontelework companies are primarily manufacturing companies, which usually have a higher proportion of fixed assets in total assets. Their mean value is less than $30 \%$, whereas the mean value of the indicator for non-telework companies is almost $40 \%$. To study this hypothesis, an analysis of the indicator of the capital ratio by sector was performed. The mean value of this indicator for all sectors was $29.90 \%$. The highest values of the indicator were achieved by enterprises operating in agriculture (52.30\% on average), followed by transport (39.40\% on average), or in the manufacturing sector (35.40\% on average), where it is obvious that fixed assets are higher. By contrast, below-average values for this indicator were achieved in wholesale, retail and services enterprises (19\% on average), 
in IT enterprises (22\% on average) and in enterprises operating in professional, scientific and technical activities ( $22.10 \%$ on average). Again, the hypothesis that telework is more adopted in these areas of business is confirmed here.

Boxplot 3: Indicators of personnel costs per employee and capital ratio of total assets in comparison with telework and non-telework companies

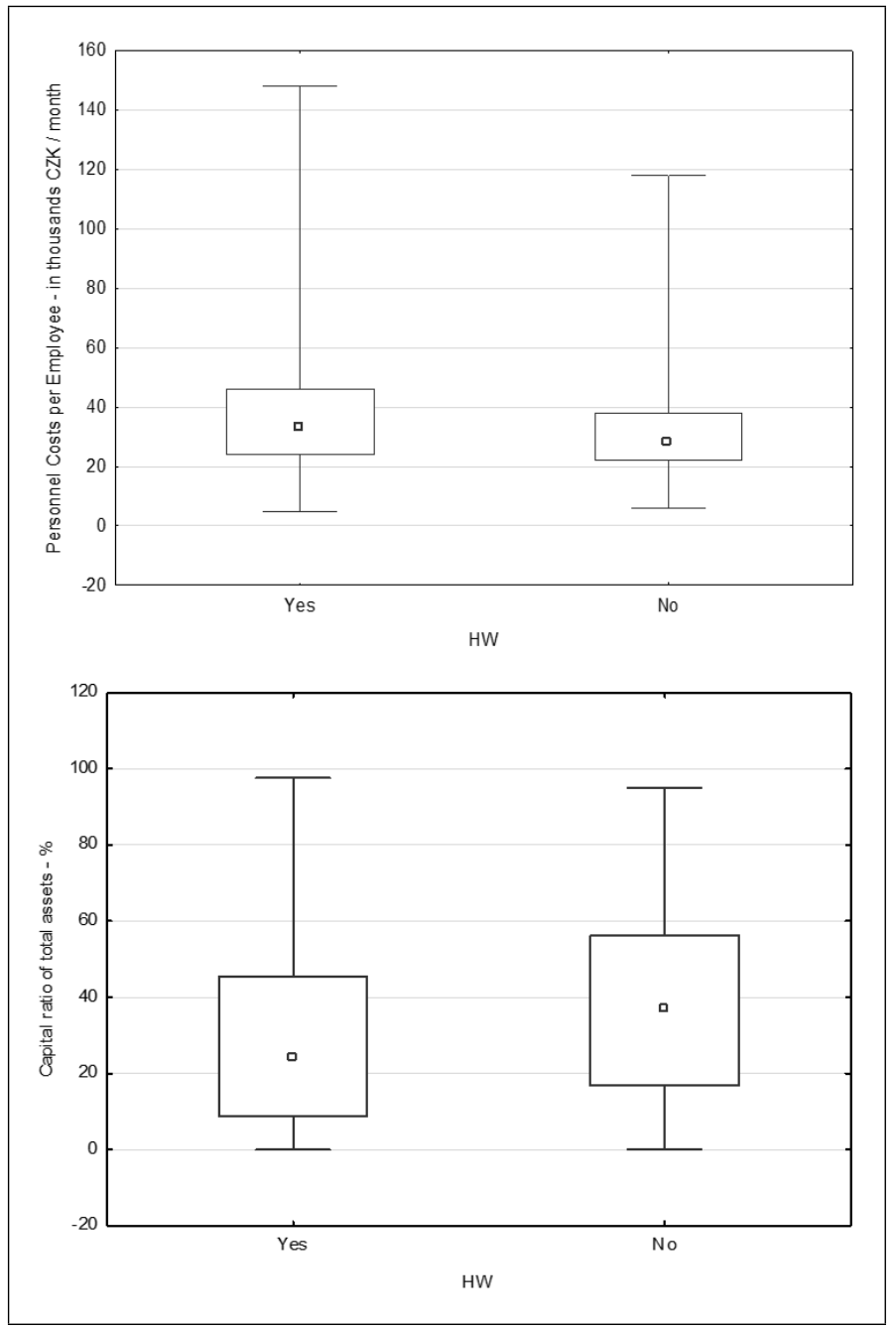

Source: Database Albertina Gold Edition, own research, authors' processing

The capital ratio of sales indicator in \% is calculated as the ratio of fixed assets/sales from the operational activity. This indicator gives information on the intensity of use of fixed assets, or what amount of fixed assets is needed to produce 1 unit of sales. According to the 
research, it is evident that the capital ratio of sales for telework companies is lower than for non-telework companies, which can be explained by the fact that telework companies there are higher sales (see labour productivity indicator) and a lower value of fixed assets (see the indicator of the capital ratio of total assets). These hypotheses were already confirmed. The equity ratio in \% is calculated as the owner's equity to total assets or total liabilities. According to the research, it is evident that equity ratio in telework companies is lower than in non-telework companies. Owner's equity represents own funds to finance the business assets of an enterprise to generate its capital. It is the main carrier of business risk. Its ration on total assets is an indicator of the company financial security. It is not a permanent variable, but a variable depending on the economic result (the EBIT analysis in each of the business sectors is listed above). If a company generates profit, equity increases, but if it shows loss, the company's own capital falls. This indicator corresponds to the indicator of debt ratio. Again, this is because telework companies use more liabilities than non-telework companies. Their mean value is around $50 \%$, while the mean value of the indicator for non-telework companies is almost $60 \%$. The indicator is the higher, the higher the equity is. The lowest values (and hence the probability that these companies are telework companies) were achieved by companies operating in the field of administration (mean value of equity is CZK 23,471.00), in the field of professional, scientific and technical activities (the mean value of the equity is CZK 31,026.00) and businesses engaged in wholesale, retail and services (the mean value of equity is CZK 39,667.00).

Inventory indicator on total assets in $\%$ is calculated as the ratio of inventories to total assets. This indicator is higher in the case of manufacturing enterprises and, as mentioned above, these enterprises do not usually use telework. Simultaneously, the indicator also corresponds to the indicator of the equity ratio, because the enterprises with a higher ratio of fixed assets also have a higher ratio of inventory. The average value of the indicator for non-telework companies is almost $15 \%$, whereas the average value of the indicator for telework companies is only around $9 \%$ - see boxplot 4 .

\section{Discussion}

Telework is an interesting alternative for the companies to organize the way their employees work. Telework statistics can be used for a range of analyzes, both macroeconomic, if we see work as one of the factors of production, and for analysis of productivity, or competitiveness in the labour market. The analyses can also be carried out from the point of view of social aspects related to the diverse ways of employing workers. Telework can help to increase the employment of parents or people with disabilities, productivity and motivation of employees and for businesses it can bring savings of office space and other facilities (Whyman and Petrescu, 2014).

A total of 16 indicators were analyzed within the surveyed enterprises, 9 indicators show the difference between telework companies and non-telework companies and 7 indicators did not show this difference. 
Boxplot 4: Equity ratio and inventory indicator on total assets in \% in comparison with telework and non-telework companies

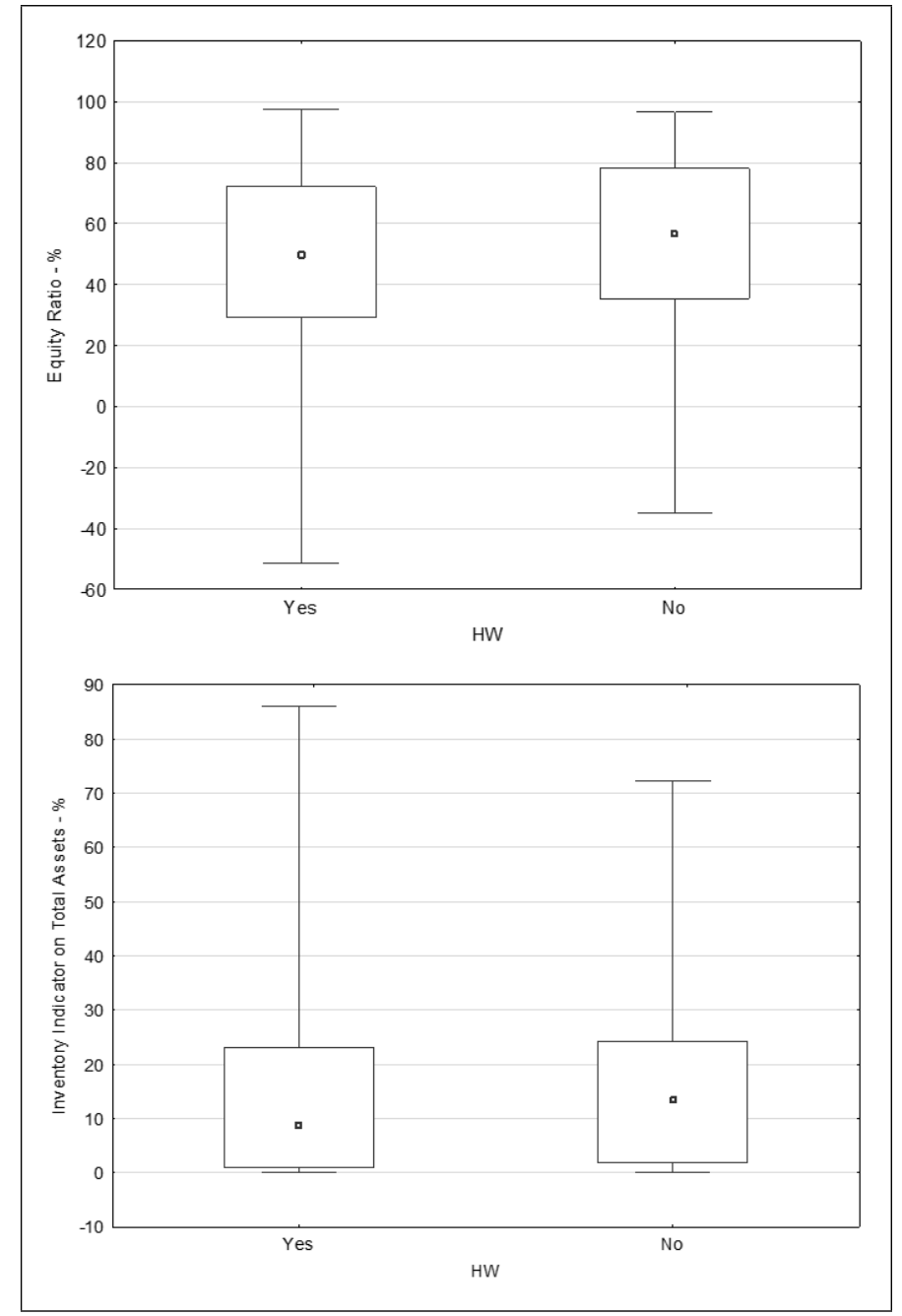

Source: Database Albertina Gold Edition, own research, authors' processing

The indicators for which there was no difference between telework and non-telework companies:

* the amount of depreciation of intangible and tangible assets,

* EBIT, i.e. pre-tax profits and interest - there are no demonstrable differences in the profit or loss between telework and non-telework companies,

* gross cash flow, 
* coverage of fixed assets,

* return on assets,

* return on sales,

* labour productivity from personnel costs.

Some indicators, however, were very interesting. For example, in case of capital ratio of total assets, which works with the total amount of fixed assets and the total amount of total assets, it was found that this indicator for telework companies is lower than for nontelework companies (see boxplot 3). It can be explained by the fact that these companies will probably have a higher ratio of long-term assets. On the other hand, the depreciation of intangible and tangible fixed assets did not show the difference between telework and not-telework companies. This may be caused by the fact that telework companies have a higher value of fixed assets, but it may lie in longer-term assets (such as buildings or halls) that are depreciated over a longer period and thus lower amounts are written off. On the other hand, non-telework companies may have fixed assets such as machines, instruments, equipment that are depreciated for a shorter period, and hence the depreciation may be the same as for buildings.

Equally interesting were the indicators of the equity ratio and the return on assets. The first mentioned showed the difference between the telework and non-telework companies, while the second indicator did not show the difference. Both denominator indicators use the same value of total capital. The indicator of the equity ratio has in the numerator owner's ratio and this indicator for telework companies is lower than for non-telework companies. The return on assets indicator has EBIT in the numerator. EBIT, i.e. earnings before interests and taxes, was another indicator where the difference was not demonstrated.

Similarly, the values of the capital ratio of the sales and return on sales worked out the same. Both indicators have the same value of total sales in the denominator. The capital ratio of the sales indicator has fixed assets in the numerator, the return on sales has EBIT in the numerator. The results, as mentioned above, are due to a higher value of fixed assets in telework companies.

The obvious disadvantage of telework are the very difficult possibility of monitoring of employee performance or deterioration in quality of work or problems with maintaining professional development and improving skills or feeling of isolation of employees (Collins, Hislop and Cartwright, 2016). Work from home is not suitable for all professions.

\section{Conclusion}

Telework is an increasingly exciting alternative to the way employees usually work. Many studies focus on the impact of distance work on efficiency, productivity, satisfaction, stress and leisure time of employees. This article deals with the evaluation of which companies (according to the financial analysis indicators) rather use or rather do not use telework.

Financial analysis is a basic source of information to assess the financial position of the company. A total of 16 indicators were assessed within the analyzed enterprises; 
the 9 indicators showed the difference between telework companies and non-telework companies. The research shows that a typical company that uses telework is a company with:

* higher ratio of liabilities and therefore lower ratio of equity,

* a lower ratio of fixed assets,

* higher sales,

* lower inventory,

* higher labour productivity and higher value added per employee,

* higher return on equity,

* higher personnel costs, higher average wages.

However, it should be noted that this is only a statistically verified hypothesis. In practice, when a manager decides whether to implement telework in a business, he must consider all its advantages and disadvantages. The company can save certain costs (for energy, premises, etc.) but it is offset by worse communication with employees, less time flexibility in assigning tasks, or isolation of employees from business events. In case of employees, telework requires a high degree of self-discipline, very good communication skills, ability to plan and perfect IT proficiency.

\section{Acknowledgements}

This paper has been supported by the Faculty of Economics of the University of South Bohemia within the Internal grant competition administrated under the ref. number EFIGS2017-Vrchota-IGS24B1.

\section{References}

Abdel-Wahab, A. (2007). Employees' attitudes towards telecommuting. An empirical investigation in the Egyptian Governorate of Dakahlia. Behaviour and Information Technology, 26(5), 367-375. https://doi.org/10.1080/01449290500535426.

Aline D., M. et al. (2012). Flexible Work Arrangements Availability and their Relationship with Work-to-Family Conflict, Job Satisfaction, and Turnover Intentions: A Comparison of Three Country Clusters. Applied Psychology, 1(1). https://doi.org/10.1111/j.14640597.2011.00453.x.

Polydoropoulou, A., Tsirimpa, A. (2012). Women's Time Use with ICT and Physical Travel in Greek Urban and Rural Areas. SPOUDAI Journal of Economics and Business, 1(2), 72 .

Armitage, R. (2000). An evaluation of secured by design housing within West Yorkshire. Home Office Briefing Note, 7, 1-4.

Bailey, D. E., Kurland, N. B. (2002). A review of telework research: Findings, new directions, and lessons for the study of modern work. Journal of Organizational Behavior. https://doi.org/10.1002/job.144. 
Baltina, I., Vitola, A. (2014). Telework v Evropě a v Lotyšsku: moderní př́istupy a budoucí perspektivy. Telework in Europe and Latvia: State-of-the-Art and Future Prospects, 8(18), 21-32.

Baruch, Y. (2000). Teleworking: Benefits and pitfalls as perceived by professionals and managers. New technology, work and employment, 15(1), 34-49.

Bělina, M., Drápal, L. (2015). Zákoník práce. Komentářr. (2nd edition), Praha: C. H. Beck. Birčiaková, N., Stávková, J., Antošová, V. (2015). Evaluating living standard indicators. DANUBE: Law, Economics and Social Issues Review, 6(3), 175-188. doi:10.1515/danb2015-0011.

Brenke, K. (2016). Home Offices: Plenty of Untapped Potential. DIW Economic Bulletin, 8, 95-104.

Brigham, E. F., Houstan, J. F. (2004). Fundamentals of Fiannacial Management. Ohio: South-Western.

Brigham, E. F., Ehrhardt, M. C. (2005). Financial Management: Theory and Practice. Ohio: South-Western.

Caulfield, B. (2015). Does it pay to work from home? Examining the factors influencing working from home in the Greater Dublin Area. Case Studies on Transport Policy, (Preprints).

Collins, A. M., Hislop, D., Cartwright, S. (2016). Social support in the workplace between teleworkers, office-based colleagues and supervisors. New Technology Work and Employment, 31(2), 161-175.

Dubrin, A. J., Barnard, J. C. (1993). What telecommuters like and dislike about their jobs. Business Forum, 18, 13-17.

Graaff, T., Rietveld, P. (2007). Substitution between working at home and out-of-home: The role of ICT and commuting costs. Transportation Research Part A: Policy and Practice, $2,142$.

Delery, J. E., Doty, D. H. (1996). Modes of theorizing in strategic human resource management: Tests of universalistic, contingency, and configurational performance predictions. Academy of Management Journal, 39, 4, 802-835. https://doi.org/10.2307/256713.

Eurofound and the International Labour Office (2017). Working anytime, anywhere: The effects on the world of work. Publications Office of European Union, Luxembourgh, and the International Labour Office, Geneva.

EWCS (2015). European Working Conditions Surveys. Brussels: Eurofound.

Gerhart, B. et al. (2000). Measurement error in research on human resources and firm performance: How much error is there and how does it influence effect size estimates? Personnel Psychology, 53, 4, 803-834. https://doi.org/10.1111/j.1744-6570.2000.tb02418.x.

Haddad, H., Lyons, G., Chatterjee, K. (2009). An examination of determinants influencing the desire for and frequency of part-day and whole-day homeworking. Journal of Transport Geography, 17, 2, 124-133. https://doi.org/10.1016/j.jtrangeo.2008.11.008.

Handy, S. L., Mokhtarian, P. L. (1995). Planning for telecommuting: Measurement and policy issues. Journal of the American Planning Association, 61, 1, 99-111. https://doi.org/10.1080/01944369508975623. 
Helminen, V., Ristimäki, M. (2007). Relationships between commuting distance, frequency and telework in Finland. Journal of Transport Geography, 15, 331-342. https://doi.org/10.1016/j.jtrangeo.2006.12.004.

Helfert, E. (2001). Financial Analysis: Tools and Techniques: A Guide for Managers. Praha: Grada.

Hill, E. J., Ferris, M., Märtinson, V. (2003). Does it matter where you work? A comparison of how three work venues (traditional office, virtual office, and home office) influence aspects of work and personal/family life. Journal of Vocational Behavior, 63, 2, 220-241. Holečková, J. (2008). Finanční analýza firmy. Praha: ASPI - Wolters Kluwer.

Hudcovský, M., Lábaj, M., Morvay, K. (2017). Employment growth and labour elasticity in V4 Countries: structural decomposition analysis. Prague Economic Papers, 2017, 26(4). Huselid, M. A. (1995). The Impact of Human Resource Management Practices on Turnover, Productivity, and Corporate Financial Performance. Academy of Management Journal, 38, 635-672. https://doi.org/10.2307/256741.

Implementation of the European Framework Agreement on Telework (2006). Report by the European Social Partners. Retrieved on January 3, 2017 from: http://resourcecentre.etuc. org/linked_files/documents/Framework\%20agreement\%20on\%20telework\%20EN.pdf.

Jiang, K. et al. (2012). How does human resource management influence organizational outcomes? A meta-analytic investigation of mediating mechanisms. Academy of Management Journal, 55, 6, 1264-1294. https://doi.org/10.5465/amj.2011.0088.

Kitou, E., Horvath, A. (2008). External air pollution costs of telework. The International Journal of Life Cycle Assessment, 13, 155. https://doi.org/10.1065/lca2007.06.338.

Kislingerová, E. (2010). Manažerské finance. Praha: C. H. Beck.

Krstić, B., Bonić, L. (2016). A new tool for intellectual capital performance measurement. Prague Economic Papers, 2016, 25(6).

Kurland, N. B., Bailey, D. E. (1999). The advantages and challenges of working here, there anywhere, and anytime. Organizational Dynamics, 28, 2, 53-68. https://doi.org/10.1016/ S0090-2616(00)80016-9.

Mannering, J. S., Mokhtarian, P. L. (1995). Modeling the choice of telecommuting frequency in California: An exploratory analysis. Technological Forecasting and Social Change, 49, 1, 49-73. https://doi.org/10.1016/0040-1625(95)00005-U.

Martin, B. H., MacDonnell, R. (2012). Is telework effective for organizations? A metaanalysis of empirical research on perceptions of telework and organizational outcomes. Management Research Review, 35, 7, 602-616. https://doi.org/10.1108/01409171211238820.

Mayo, M. et al. (2009). Why some firms adopt telecommuting while others do not: A contingency perspective. Human Resource Management, 48, 6, 917-939. https://doi.org/ 10.1002/hrm.20322.

McCloskey, D. W., Igbaria, M. (1998). A review of the empirical research on telecommuting and directions for future research. In The virtual workplace. Hershey, USA: Idea Group Publishing.

Morgan, R. E. (2004). Teleworking: an assessment of the benefits and challenges. European Business Review, 16, 4, 344-357. https://doi.org/10.1108/09555340410699613. 
Muhammad, S., Ottens, H. F. L., Jong, T. (2008). Modelling the impact of telecommuting on future urbanisation in the Netherlands. Tijdschrift Voor Economische En Sociale Geografie: TESG, 99, 2, 160-177.

Neumaierová, I., Neumaier, I. (2009). Proč se ujal index IN a nikoli pyramidový systém ukazatelů INFA. GAČR Generátory tvorby hodnoty. 2009, N/A. Retrieved from: http://www.ekonomikaamanagement.cz/getFile.php?fileKey=CEJVB0NUCAdVCEZIU1VHB0MIUUMEBAVDVFVWQ1VUBAVGQ1VCXgQFBERIREJLYg.

Nilles, J. M. (1998). Managing telework: Strategies for managing the virtual workforce. New York: John Wiley and Sons.

Peters, P., Lippe, T. (2007). The time-pressure reducing potential of telehomeworking: the Dutch case. International Journal of Human Resource Management, 18, 3, 430-447. https://doi.org/10.1080/09585190601167730.

Peters, P., Dulk, L., Ruijter, J. (2010). May I work from home? Views of the employment relationship reflected in line managers' telework attitudes in six financialsector organizations. Equality, Diversity and Inclusion: An International Journal, 29, 5, 517-531. https://doi.org/10.1108/02610151011052799

Potter, E. E. (2003). Telecommuting: The future of work, corporate culture, and American society. Journal of Labor Research, 24, 1, 73-84. Retrieved from: http://www.scopus.com/ inward/record.url?eid=2-s2.0-0037413135\&partnerID=40\&md5=2aaa2498265d63488df1991e9cd26a11.

Ramsower, R. (1985). Telecommuting: The organizational and behavioral effects of working at home. Ann Arbor, MI: UMI Research.

Ravi, S. G., David, A. H. (2007). The Good, the Bad, and the Unknown About Telecommuting: Meta-Analysis of Psychological Mediators and Individual Consequences. Journal of Applied Psychology, 6, 1524. https://doi.org/10.1037/0021-9010.92.6.1524.

Redman, T., Snape, E., Ashurst, C. (2009). Location, Location, Location: Does Place of Work Really Matter? British Journal of Management, 20, 171-181. https://doi.org/10.1111/j.1467-8551.2008.00640.x.

Saim M. et al. (2007). Telecommuting and residential locational preferences: a case study of the Netherlands. Journal of Housing and the Built Environment, 4, 339.

Seung-Nam K. (2016). Two traditional questions on the relationships between telecommuting, job and residential location, and household travel: revisited using a path analysis. The Annals of Regional Science, 2, 537. https://doi.org/10.1007/s00168-0160755-8.

Scholleová, H. (2008). Ekonomické a finanční ř́zení pro neekonomy. Praha: Grada Publishing.

Steil, A. V., Barcia, R. M. (2001). An Assessment Model to Analyze Organizational Readiness to Implement Telework Arrangements. E-Business and Virtual Enterprises, 455-464. https://doi.org/10.1007/978-0-387-35399-9_44.

Synek, M. (2011). Manažerská ekonomika. Praha: Grada Publishing.

Tayyaran, M. R., Khan, A. M. (2007). Telecommuting and residential location decisions: combined stated and revealed preferences model. Canadian Journal of Civil Engineering, 34, 10, 1324-1333. https://doi.org/10.1139/L07-052. 
Verbeke, A. et al. (2008). Growing the Virtual Workplace: The Integrative Value Proposition for Telework, Cheltenham. UK \& Northampton, US: Edward Elgar.

Vilhelmson, B., Thulin, E. (2016). Who and where are the flexible workers? Exploring the current diffusion of telework in Sweden. New Technology, Work and Employment, 31, 1, 77-96. https://doi.org/10.1111/ntwe.12060.

Wild, J. (2005). Financial statement analysis. Boston: McGraw-Hill Irwin.

Whyman, P. B., Petrescu, A. I. (2014). Partnership, flexible workplace practices and the realisation of mutual gains: evidence from the British WERS 2004 dataset. International Journal of Human Resource Management, 25, 6, 829-851. 